WASANA NYATA : Jurnal Pengabdian kepada Masyarakat ISSN : $\underline{2580-8443}$

Vol.4, No.1 April (2020); p.50-56; https:/le-journal.stie-aub.ac.id/index.php/wasana_nyata

\title{
UPGRADING MINAT WIRAUSAHA SISWA DALAM RANGKA OPTIMALISASI POTENSI DAERAH YANG DALAM MEMBANGUN KEMANDIRIAN EKONOMI
}

\author{
Irwan Christanto Edy ${ }^{1)}$ Shandy Marsono ${ }^{2)}$ Heriyanta Budi Utama ${ }^{3)}$ \\ Dosen program studi S1 Manajemen STIE AUB Surakarta \\ Email : irwan_aub@yahoo.co.id
}

\begin{abstract}
Pengangguran merupakan permasalahan sosial yang membutuhkan penanganan yang serius karena akan berdampak pada permasalahan sosial lainnya seperti kriminalisme, kemiskinan dan penyakit masyarakat. Salah satu solusi mengatasi pengangguran adalah program kewirausahaan. Program kewirausahaan lebih baik kalau dimulai dari jenjang pendidikan formal, dan jiwa wirausaha harus ditanamkan kepada siswa sejak dini. Pendidikan kewirausahaan berbasis sekolah sangat tepat diterapkan pada jenjang pendidikan SMK, karena lulusan SMK merupakan lulusan siap kerja di masyarakat. PKM bagi siswa SMK Negeri 7 Surakarta ini bertujuan untuk memberikan bekal pengetahuan, dan ketrampilan yang akan meningkatkan sikap dan motivasi siswa dalam berwirausaha. Kewirausahaan siswa merupakan kewirausahaan yang mengoptimalkan kemampuan siswa untuk berinovasi dan berkreasi dalam membangun bisnis sesuai dengan kompetensinya. Dalam kewirausahaan siswa ini dukungan prasarana, guru, karyawan, komite menjadi kunci dalam pendidikan kewirausahaan di sekolah SMK. Metode yang digunakan dalam kegiatan ini dengan memberikan pelatihan dan pendampingan pada siswa SMK. Dalam kegiatan ini Tim pelaksana bermitra dengan SMK Negeri 7 Surakarta Jawa Tengah. Kegiatan ini memberikan hasil yaitu (1) peningkatan pengetahuan berwirausaha (2) peningkatan motivasi dan minat siswa untuk wirausaha, (3) meningkatnya ketrampilan dalam mengelola usaha. Kegiatan ini akan sangat memberikan manfaat bagi siswa sebagai calon wirausaha yang berhasil.
\end{abstract}

Kata kunci : Kewirausahaan, Siswa, Pelatihan dan Pendampingan, Sekolah Menengah Kejuruan (SMK)

\section{A. Pendahuluan}

Pada sisi lain, permasalahan yang muncul jumlah angka pengangguran di Indonesia selalu meningkat setiap tahunnya. Angka pengangguran terbesar pada lulusan Sekolah Menengah Kejuruan (SMK). Peningkatan angka pengangguran tersebut selalu dikaitkan dengan sekolah atau lembaga pendidikan, selaku lembaga yang memproduk calon-calon tenaga kerja tersebut. Para pengelola sekolah (kepala sekolah, guru) menjadi sorotan semua pihak baik itu pengamat pendidikan, politisi, bahkan pemerintah sendiri karena dianggap tidak dapat menghasilkan lulusan yang berkualitas. Pengangguran ini terjadi karena lapangan pekerjaan yang tersedia tidak mampu menampung jumlah angkatan kerja yang ada, atau dengan kata lain laju pertambahan tenaga kerja tidak sebanding dengan pertumbuhan lapangan pekerjaan.

Data dari BPS (2010: 73), satu di antara 10 angkatan kerja kini berstatus penganggur. Padahal menurut penelitian, setiap pertumbuhan ekonomi 1 persen hanya mampu menciptakan sebanyak sekitar 265.000 lapangan kerja baru. Dengan pertumbuhan ekonomi Indonesia yang berkisar antara 6 persen, maka hanya tersedia sebanyak sekitar 1.590.000 lapangan kerja baru. Kewirausahaan merupakan salah satu solusi mengatasi pengangguran (hakim, 1998; Hers, 1980). Pendidikan kewirausahaan dapat dimulai dari sekolah (Arismunandar, 2006). Kurikulum yang diterapkan di sekolah sekarang ini cenderung teoritis, hal ini turut memberikan kontribusi kepada ketidaksiapan lulusan untuk memilih karir kerja mandiri (selfemployment) atau berwirausaha karena siswa hanya disiapkan untuk melanjutkan atau masuk perguruan tinggi. Demikian pula lulusan perguruan tinggi pada umumnya dipersiapkan untuk bekerja menjadi karyawan. Memilih karir berwirausaha merupakan kasus luar biasa, kecuali bagi siswa yang 
memiliki latar belakang keluarga wirausaha terutama dari kalangan warga etnis keturunan. Pendidikan kewirausahaan berbasis sekolah harus kreatif dan inovatif (Buchari, 2006; Bor et al.,1989; Kao, 1989) dan tidak dapat dilepaskan dari karakter bangsa (Binsar, 2010; Tyasno, 2007; Maksum dan Luluk, 2004; Magnis, 1987).

Berdasarkan fenomena di atas, menurut beberapa ahli salah satu upaya yang dapat dilakukan oleh SMK untuk meminimalisasi pengangguran tersebut adalah memberikan pendidikan kewirausahaan (entrepreneurship) semenjak dini, sehingga para siswa memiliki bekal spirit yang tinggi yaitu mandiri, berani menanggung resiko dan mampu memanfaatkan peluang sekecil apapun serta memiliki jiwa tidak mudah menyerah. Mencermati berbagai permasalahan tersebut di atas, tim pelaksana PKM akan mencoba menawarkan Model Kewirausahaan Berbasis Sekolah pada Siswa SMK (Sekolah Menengah Kejuruan) dengan studi kasus pada SMK N 7 Surakarta.

SMK (Sekolah Menengah Kejuruan) Negeri 7 Surakarta merupakan salah satu sekolah SMK dikota Surakarta yang cukup tua dan terkenal yang memiliki jurusan yang lengkap yaitu pekerjaan sosial, multimedia, broadcasting, akomodasi perhotelan, usaha perjalanan wisata, jasa boga dan patiseri. Jasa boga merupakan andalan andalan dari SMK ini, sehingga perlu kembangkan lebih lanjut. Fasilitas yang tersediapun cukup lengkap dari gedung pertemuan, ruang kelas, edotel sampai pada tempat uji kompetensi.

Kendala kendala penerapan kewirausahan di sekolah SMK cukup kompleks. Mulai dari Kurikulum, sarana prasarana, tenaga pendidikan dan dukungan akses permodalan. Kurikulum pembelajaran masih mengacu pada pedoman pembelajaran dari Dinas Pendidikan Provinsi Jawa Tengah. Dalam kurikulum tersebut masih memberikan ruang kewirausahaan siswa yang masih terbatas dan minim. Dalam keterbatasan pendidikan kewirausahaan pada kurikulum sekolah SMK ini, yang kurang memberikan motivasi untuk siswa SMK berwirausaha.

\section{B. Kajian Teori Kewirausahaan}

Kewirausahaan adalah padanan kata dari entrepreneurship dalam bahasa Inggris, unternehmer dalam bahasa Jerman, ondernemen dalam bahasa Belanda. Sedangkan di Indonesia diberi nama kewirausahaan. Kata entrepreneurship sendiri sebenarnya berawal dari bahasa Prancis yaitu „entreprende yang berarti petualang, pencipta, dan pengelola usaha. Istilah ini diperkenalkan pertama kali oleh Richard Cantillon (1755). Istilah ini makin populer setelah digunakan oleh pakar ekonomi J.B Say (1803) untuk menggambarkan para pengusaha yang mampu memindahkan sumber daya ekonomis dari tingkat produktivitas rendah ke tingkat yang lebih tinggi serta menghasilkan lebih banyak lagi. Sebenarnya telah banyak pakar yang mengemukakan pengertian mengenai kewirausahaan berdasarkan sudut pandangnya masingmasing. Namun demikian, esensi pengertian yang krusial senantiasa ada di setiap pengertian yang dikemukakan oleh para ahli tersebut dan menjadi hal mendasar

Peter F. Drucker mengatakan bahwa kewirausahaan merupakan kemampuan dalam menciptakan sesuatu yang baru dan berbeda. Definisi tersebut secara lebih luas dikemukakan oleh Hisrich dalam Suryana, yang mengatakan bahwa kewirausahaan adalah proses penciptaan sesuatu yang berbeda untuk menghasilkan nilai dengan mencurahkan waktu dan usaha, diikuti penggunaan uang, fisik, risiko, dan kemudian menghasilkan balas jasa berupa uang serta kepuasan dan kebebasan pribadi. Sementara itu, Zimmerer mengartikan kewirausahaan sebagai suatu proses penerapan kreativitas dan inovasi dalam memecahkan persoalan dan menemukan peluang untuk memperbaiki kehidupan (usaha). Dalam Instruksi 
WASANA NYATA : Jurnal Pengabdian kepada Masyarakat ISSN : $\underline{\mathbf{2 5 8 0 - 8 4 4 3}}$

Vol.4, No.1 April (2020); p.50-56; https://e-journal.stie-aub.ac.id/index.php/wasana_nyata

Presiden (Inpres) Nomor 4 tahun 1995 tanggal 30 Juni 1995 tentang Gerakan Nasional Memasyarakatkan dan Membudayakan Kewirausahaan, bahwasanya ; "Kewirausahaan adalah semangat, sikap, perilaku dan kemampuan seseorang dalam menangani usaha dan kegiatan yang mengarah pada upaya mencari, menciptakan, menerapkan cara kerja, teknologi dan produksi baru dengan meningkatkan efisiensi dalam rangka memberikan pelayanan yang lebih baik dan atau memperoleh keuntungan yang lebih besar.

Masykur Wiratmo dalam buku Pengantar Kewiraswastaan Kerangka Dasar Memasuki Dunia Bisnis mengungkapkan definisi kewirausahaan sebagai proses penciptaan sesuatu yang berbeda nilainya dengan menggunakan usaha dan waktu yang diperlukan, memikul risiko finansial, psikologi, dan sosial yang menyertainya, serta menerima balas jasa finansial dan kepuasan pribadi.

Kata entrepreneur atau wirausaha dalam bahasa Indonesia merupakan gabungan dari wira (gagah, berani, perkasa) dan usaha (bisnis) sehingga istilah entrepreneur dapat diartikan sebagai orang yang berani atau perkasa dalam usaha/bisnis. Menurut Josep Schumpeter wirausaha adalah orang yang mendobrak sistem ekonomi yang ada dengan memperkenalkan barang dan jasa yang baru, dengan menciptakan bentuk organisasi baru atau mengolah bahan baku baru. Secara sederhana arti wirausaha (entrepreneur) adalah orang yang berjiwa berani mengambil risiko untuk membuka usaha dalam berbagai kesempatan. Berjiwa berani mengambil risiko artinya bermental mandiri dan berani memulai usaha, tanpa diliputi rasa takut atau cemas sekalipun dalam kondisi tidak pasti. Dalam Wikipedia, entrepreneur adalah an owner or manager of a business enterprise who makes money through risk and initiative. Artinya, pemilik atau manager sebuah perusahaan bisnis yang menghasilkan keuntungan melalui pengambilan risiko dan tindakan inisiatif. Secara konseptual, seorang wirausahawan dapat didefinisikan dari beberapa sudut pandang dan konteks. Bagi ahli ekonomi seorang entrepreneur adalah orang yang mengkombinasikan resources, tenaga kerja, material dan peralatan lainnya untuk meningkatkan nilai yang lebih tinggi dari sebelumnya, dan juga orang yang memperkenalkan perubahan-perubahan, inovasi, dan perbaikan produksi lainnya. Bagi seorang psychologist seorang wirausaha adalah seorang yang memiliki dorongan kekuatan dari dalam untuk memperoleh sesuatu tujuan, suka mengadakan eksperimen atau untuk menampilkan kebebasan dirinya di luar kekuasaan orang lain. Bagi seorang businessman atau wirausaha adalah merupakan ancaman, pesaing baru atau juga bisa seorang partner, pemasok, konsumen atau seorang yang bisa diajak kerjasama. Bagi seorang pemodal melihat wirausaha adalah seorang yang menciptakan kesejahteraan buat orang lain, yang menemukan cara-cara baru untuk menggunakan resources, mengurangi pemborosan, dan membuka lapangan kerja yang disenangi oleh masyarakat.

\section{Materi dan Metode}

Dengan permasalahan yang ada, maka tim pelaksana Pengabdian pada Masyarakat STIE-AUB Surakarta menawarkan penyelesaian dalam bentuk memberikan pelatihan dan pendampingan tentang bisnis keluarga. Adapun materi pelatihan yang akan diberikan kepada siswa SMK N 7 Surakarta adalah:

1. Penyuluhan tentang wirausaha

Penyuluhan adalah memberi kejelasan untuk menolong seseorang menemukan jalannya. Penyuluhan sebagai pemberian saran yang berarti seseorang dapat memberikan petunjuk bagi seseorang tetapi seseorang tersebut yang berhak untuk menentukan pilihannya. 
Penyuluhan secara umum adalah proses pendidikan nonformal yang diberikan kepada seseorang dengan tujuan agar orang dapat memecahkan masalahnya sendiri khususnya dalam bidang yang di tekuni dan meningkatkan pendapatan.

Pengertian penyuluhan (Mardikantoro, 1993) adalahproses penyebarn informasi berkaitan dengan upaya perbaikan cara-cara berusaha demi tercapainya pendapatan dan perbaikan kesejahteraan.

2. Pelatihan tentang membangun usaha

Pelatihan mempersiapkan peserta latihan untuk mengambil jalur tindakan tertentu yang dilukiskan oleh teknologi dan organisasi tempat bekerja, dan membantu peserta memperbaiki prestasi dalam kegiatannya terutama mengenai pengertian dan keterampilan. (Rolf P. Lynton dan Udai Pareek, Pelatihan dan Pengembangan Tenaga Kerja, Pustaka Binaman Jakarta 1998)

3. Pendampingan praktek tentang wirausaha

Pendampingan atau lebih dikenal dengan istilah Mentorship. Mentorship berakar kata dari Mentor dalam Kamus Besar Bahasa Indonesia (KBBI) memiliki makna pembimbing atau pengasuh. ${ }^{[1]}$ Secara istilah ditemukan banyak sekali definisi terhadap kata Mentoring, tercatat hingga tahun 2007 ada lebih dari 50 definisi yang menggambarkan makna dari Mentoring. Dalam buku karya Gendro Salim yang berjudul Effective Coaching, ia memberikan memaknai Mentoring sebagai sebuah aktivitas bimbingan dari seseorang yang sudah sangat menguasai hal-hal tertentu dan membagikan ilmunya kepada orang yang membutuhkannya. Orang yang melakukan kegiatan mentoring disebut dengan Mentor sedangkan orang yang di-mentor-i disebut Mentee.

4. Diskusi dan Sharing kewirausahaan

Diskusi adalahsebuah interaksi komunikasi antar dua orang atau lebih kelompok.

Biasanya komunikasi antara mereka kelompok tersebut berupa salah satu ilmu atau pengetahuan dasar yang akhirnya akan memberikan rasa pemahaman baik dan benar. Diskusi bisa berupa apa saja yang awalnya disebut topik. Dari topik inilah diskusi berkembang dan diperbincangkan yang pada akhirnya akan menghasilkan suatu pemahaman dari topik.

\section{Hasil dan Pembahasan}

Solusi mengatasi permasalahan pendidikan wirausaha siswa secara ringkas dapat digambarkan dalam alur yang terdiri dari 9 tahap tahap sebagai berikut : 


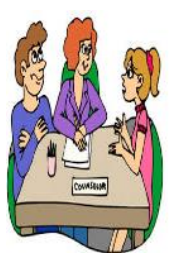

Tahap

(1)

Rapat Pemilih

Koordin an 25

asi

"Persiap

an

Kegiata

n"

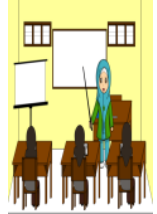

Tahap

(3)

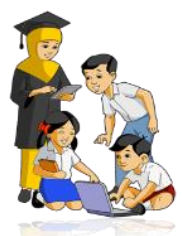

Tahap

(4)

Program

Penyuluh

an an

"Kewirau "Studi

sahaan"

kelayakan

Bisnis"

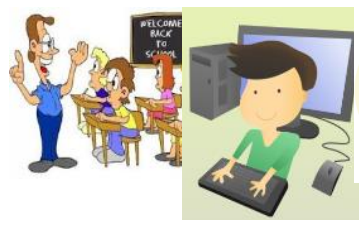

Tahap

(5)

Diskusi

dan

Sharing

"Model

KWU"
Tahap

(6)

Evaluasi

Kegiata

$\mathrm{n}$

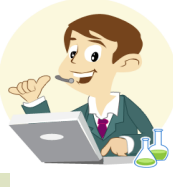

Tahap (7)

Penyusun

an

Laporan

Kegiatan

PKM

Secara umum solusi dari permasalahan mitra dapat dilakukan hal hal sebagai berikut :

1. Dalam rangka meningkatkan pengetahuan tentang kewirausahaan dan bisnis pada siswa, dapat dilakukan dengan kegiatan memberikan penyuluhan /ceramah/ kuliah tentang manajemen produksi, manajemen pemasaran, manajemen keuangan.

2. Dalam rangka meningkatkan pengetahuan dan ketrampilan dalam mengawali usaha/bisnis pada siswa, dapat dilakukan dengan kegiatan memberikan pelatihan atau workshop tentang studi kelayakan bisnis, yang dikuti dengan pelatihan membuat proposal bisnis.

3. Dalam rangka, meningkatkan motivasi, minat, dan sikap untuk wirausaha bagi siswa dapat dilakukan dengan kegiatan mengundang tokoh wirausaha yang telah sukses menjalankan bisnis sebagai Role Model (Model Peran) dengan studi kasus wirausaha bidang jasa boga. 
4. Dalam rangka meningkatkan pengetahuan dan ketrampilan wirausaha bagi siswa dapat dilakukan dengan kegiatan praktek bisnis kuliner sesuai dengan jrusan jasa boga.

5. Meningkatkan ketrampilan wirausaha siswa dapat dilakukan dengan melakukan pendampingan dan menyediakan wadah yang berupa unit usaha yang produktif seperti buka warung kuliner, kantin sekolah dsb.

Pencapaian luaran secara kualitatif yang diperoleh dari kegiatan pengabdian kepada masyarakat dalam hal ini adalah kelompok siswa SMK Negeri 7 Surakarta ini adalah :

1. Secara kualitatif, yang ingin dicapai dari kegiatan ini adalah:

a. Siswa SMK Negeri 7 Surakarta memiliki rasa senang dan suka terhadap kegiatan usaha, tidak ada keterpaksaan dan motivasi meningkat dalam wirausaha.

b. Siswa memiliki ketertarikan untuk membuka usaha usaha khususnya melanjutkan usaha keluarga.

c. Siswa memiliki perhatian, konsentrasi dan aktifitas jiwa rasa ingin tahu untuk berwirausaha.

d. Siswa memliki keterlibatan terhadap kegiatan kewirausahaan yang telah diadakan pihak sekolah

e. Mendorong motivasi guru dan sekolah untuk menciptakan kurikulum kewirausahaan yang lebih efektif dan produktif dalam menciptakan wirausaha siswa

2. Secara kuantitatif sebagai berikut :

a. Jumlah kehadiran siswa untuk mengikuti kegiatan pelatihan kewirausahaan meningkat $60 \%$

b. Beban tugas pendidikan kewirausahaan pada kurikulum meningkat $20 \%$

3. Manfaat Potensi Ekonomi

a. Untuk memberikan nilai tambah terhadap peningkatan kualitas dan kuantitas sumber daya manusia khususnya siswa SMK

b. Untuk meningkatkan kesejahteraan ekonomi siswa dan keluarganya

\section{E. Kesimpulan dan Saran}

1. Kesimpulan

Berdasarkan kajian situasi tim pengabdian pada masyarakat telah menyelenggarakan kegiatan pendampingan dan pelatihan kewirausahaan khususnya untuk siswa SMK. Dalam program pengabdian pada masyarakat ini hasil yang telah tercapai adaah : 1)siswa makin memiliki pemahaman tentang kewirausahaan, 2)siswa memiliki minat dan mtoivasi untuk berwirausaha. Kegiatan ini telah berjalan dengan baik dan mampu meningkatkan motivasi dan minat siswa SMK.

2. Saran dan Tindak lanjut

Tidak lanjut dari kegiatan pengabdian pada masyarakat untuk siswa SMK Negeri 7 Surakarta ini adalah pendampingan usaha kewirausahaan, yang dapat diwujudkan dengan kerjasama bisnis 


\section{DAFTAR PUSTAKA}

Arismunandar. (2006). Pengembangan Kewirausahaan Sekolah, Direktorat Tenaga Kependidikan Departemen Pendidikan Nasional, Jakarta.

Buchari, (2006). Kewirausahaan Sekolah Berbasis Kreativitas dan Inovasi, Direktorat Tenaga Kependidikan Departemen Pendidikan Nasional, Jakarta.

Binsar A. Hutabarat. (2010). Karakter bangsa, dulu dan kini, dari file:///G/karakter_bangsa_dulu_dan_kini.html.diunduh 27 April 2010.

Borg R Walter, Gall Mredith D, (1989), Educational research, an intruduction,Routledge, New York.ogdan, Robert C, Biklen, Knopp Sari, (1982), Qualitative Research fo Eduactin, An Int

Hakim, Rusman. (1998). Dengan Berwiraswasta Menepis Krisis: KonsepMembangun Masyarakat Entrepreneur Indonesia, Alex Media Komputindo,Jakarta.

Hers. Richard H. et al. (1980). Model of moral education: An Appraisal. NewYork: Longman Inc.

Kao, John, (1989), Entrepreneurship, Creativity \& Organization, Harvad BusinessSchool, Prentice Hall, Englewood, New Jersey.

Ki Tyasno Sudarto. (2007). "Pengembangan nilai-nilai luhur budi pekerti sebagai karakter bangsa” dari file/H./Pengembangan/ 20 Nilai-nilai/20Luhur/20Budi/Pekerti. Diakses 12 Maret 2010.

Maksum dan Luluk YR. (2004). Paradigma pendidikan universal di era modern dan post modern, Yogyakarta: Penerbit Sarasin.

Magnis Suseno Frans. (1987). Etika dasar; masalah-masalah pokok filsafat moral, Jakarta: Penerbit Kanisius.

Mas'ud Machfoedz (2004). Iklim Organisasi Kreatif, Manajemen USAHAWAN Indonesia, No. 09/TH XXXIII September 2004.

Rusman, Hakim, (1998). Dengan Berwiraswasta Menepis Krisis: Konsep Membangun Masyarakat Entrepreneur Indonesia, Alex Media Komputindo, Jakarta.

. (2007). Kewirausahaan Sekolah Berbasis Kreativitas dan Inovasi, Direktorat Tenaga

Kependidikan Departemen Pendidikan Nasional, Jakarta. 